\title{
Gross $\alpha$ and $\beta$ Activity Concentration and Estimation of Adults and Infants Dose intake in Surface and Ground Water of Ten Oil Fields Environment in Western Niger Delta of Nigeria \\ ${ }^{* 1}$ EZEKIEL O. AGBALAGBA; ${ }^{2}$ GREGORY O. AVWIRI; ${ }^{3}$ YEHUWDAH E. CHAD- UMOREN
}

\author{
${ }^{I}$ Department of Physics, Federal University of Petroleum Resources, Effurun, Delta State, Nigeria. \\ ${ }^{2,3}$ Department of Physics, University of Port Harcourt, Port Harcourt, Rivers State, Nigeria
}

ezeke64@yahoo.com,goavwiri@yahoo.com and echadumoren@yahoo.com

\begin{abstract}
The oil and gas rich Niger Delta region of Nigeria is characterized by environmental degradation leading to environmental pollution from oil and gas activities. This study examined the gross $\alpha$ and $\beta$ activity in thirty (river/stream, well and tap) water samples collected from ten oil fields in the Western Niger Delta region of Nigeria. The counting system employed in this analysis is the Gas-flow proportional counter \{Eurisys Measure IN20 low- background multiple (eight) channel counter\}. Gross alpha activity concentration range from $0.01 \pm 0.002$ to $0.7 \pm 0.01(0.15 \pm 0.003) \mathrm{Bql}^{-1}, 0.01 \pm 0.003$ to $0.5 \pm 0.01(0.1 \pm 0.003) \mathrm{Bql}^{-1}$ and $0.02 \pm 0.001$ to $35.1 \pm 1.1(4.1 \pm 0.1) \mathrm{Bql}^{-1}$ while beta activity concentration ranged from $1.1 \pm 0.04$ to $13.2 \pm 0.1(6.0 \pm 0.1) \mathrm{Bql}^{-1}, 0.7 \pm 0.1$ to $54.7 \pm 1.3$ $(8.9 \pm 0.2) \mathrm{Bql}^{-1}$ and $0.7 \pm 0.03$ to $151.2 \pm 1.8(40.1 \pm 0.9) \mathrm{Bql}^{-1}$ for well, tap and river waters respectively. Correlation value between $\alpha$ and $\beta$ activities in well, tap and river water is $0.025,0.047$ and 0.512 respectively. The results show that except for the alpha activity in the tap water samples, the average natural activity concentrations of $\alpha$ - and $\beta$-emitting radionuclides in the samples are slightly above the WHO recommended limit. For all samples the gross $\beta$ activities are higher than the corresponding gross $\alpha$ activities. The mean effective equivalent dose intake per year due to alpha activity in the water samples for adults and infants are: $76.4 \pm 1.8$ and $20.9 \pm 55 \mu \mathrm{Svy}^{-1}, 54.6 \pm 1.3$ and $14.9 \pm 0.4 \mu \mathrm{Svy}^{-1}$, and $2118 \pm 70$ and $584 \pm 19.2 \mu \mathrm{Svy}^{-1}$ in well, tap, and river water samples respectively. The results obtained for dose intake are below the WHO recommended reference level of $0.1 \mathrm{mSvy}^{-1}$, except for the water sample from Uzere river. This study indicates that the water sources evaluated, especially the rivers, are contaminated radiologically. @JASEM
\end{abstract}

\section{DOI: http://dx.doi.org/10.4314/jasem.v17i2.10}

The oil rich Niger Delta people are becoming increasingly and understandably worried about the safety of their drinking water due to frequent oil spill into surface and ground water. Petroleum is a naturally occurring liquid mineral deposited beneath the earth's surface. Its occurrence is sometimes accompanied with the presence of natural gas. The oil and associated gases are generally contaminated with radionuclides within the earth's crust. These provide the source of radiation such as $\alpha, \beta$ and $\gamma$ often found in the petroleum matrix (Chad-Umoren, 2012; Laogun et al, 2006).

But human activities such as mining, milling and processing of uranium ores and mineral sands, manufacture of fertilizers, drilling, transportation, processing and burning of fossil fuels have raised the concentrations of naturally occurring radioactive materials in the environment (Pujol and SanchezCabeza, 2000). Enhanced levels of these naturally occurring radionuclides might be present in surface and ground water in areas that are rich in natural radionuclides. This can occur when anthropogenic activities such as oil exploration and exploitation takes place in an environment, oil spill in surface water, wash away and seepage into underground water resulting in Technologically-Enhanced Naturally-Occurring Radioactive Materials (TENORM) (El-Gamal et al., 2007). Water is indispensable to human life and is therefore an important parameter of environmental science. The presence of radionuclides in drinking water poses a number of health hazards, especially when the radionuclides are deposited in the human body, through drinking the polluted water. For practical screening purposes in the case of drinking water, the 
recommended guideline activity concentrations are $0.1 \mathrm{Bql}^{-1}$ for gross alpha and $1.0 \mathrm{Bql}^{-1}$ for gross beta activity (WHO, 1993; 2003). These recommendations do not differentiate between natural and man-made radionuclides. In line with the WHO standard, the Institute of Turkish Standard recommended guidelines for activity concentration in drinking water are $0.1 \mathrm{Bql}^{-1}$ for gross alpha and $1.0 \mathrm{Bql}^{-1}$ for gross beta activity (Damla, et al., 2006).

The reason for evaluating the gross alpha and gross beta activities is to ensure that the reference dose level (RDL) of committed effective dose of $0.1 \mathrm{mSvy}$ ${ }^{1}$ consumption of drinking water is not exceeded in any study (oil and gas exploitation) area. The RDL of $0.1 \mathrm{mSv}$ is equal to $10 \%$ of the dose limit for members of the public, recommended by the International Commission for Radiological Protection (ICRP, 1991) and the International Basic Safety Standard (IAEA, 1996). Also, they are acceptable to most World Health Organization (WHO) member States, the European Commission, and the Food and Agriculture Organization (Muhammad et al., 2010).

The objectives of this study is to evaluate the gross alpha and beta radioactivity in water from well water, boreholes and river/creek water in ten oil fields and their host communities in Land Production area of Delta state, Western Niger Delta of Nigeria, and to establish the distribution pattern of radioactivity measured in the study area. This is to ascertain the safety of both surface and ground water for drinking.

\section{MATERIALS AND METHODS}

Study Area : This study was carried out in oil fields located within the oil mining lease 30 (OML 30) onshore Western Niger Delta of Nigeria (Fig. 1). Ten oil fields were strategically selected to represent the over forty onshore oil fields. The study area lies within latitudes $5^{0} 18$ 'N and $5^{0} 68^{\prime \prime} \mathrm{N}$ and longitudes $5^{0} 33$ "E and $6^{\circ} 40^{\prime \prime} \mathrm{E}$ West of Niger delta region of Nigeria. The main geological elements of the area at varying depths in thousands of meters are the Benin formation (which is the youngest) underlain by the Agbada formation and then followed by the oldest, the Akata formation. These three formations are differentiated by their ages and by degrees of compaction. Their ages become progressively younger in a down-dip direction (Taiwo and Akalia, 2009). The Benin formation is the main aquifer in the study area and regionally, is the main aquifer of the Western Niger Delta (SPDC, EIA, 2004). The groundwater table ranges between $8 \mathrm{ft}-10 \mathrm{ft}$. The natural water system of the area, depending on the location and depth belongs to two extremes of fresh and salt water with an intermediary represented by the brackish water (SPDC, EIA, 2004).

Sample Collection and Preparation: The thirty water samples used were collected from rivers/streams in close proximity to the oil fields and from the community public water supply sources (taps and wells). The samples were collected in 2-litre plastic containers with about $1 \%$ air space left for thermal expansion. To minimize contamination, the containers were first rinsed three times with sample water before use. Well water samples were collected manually in the early hours of the day from community wells of varying depths (5-10m). Tap water samples were collected at laminar flow rate after first turn on at full capacity for several minutes to purge the plumbing system of any water which might contaminate sample, to reduce radon loss (Tchokossa, et al., 1999). Sample collection procedure for river/stream water collection is as reported by (Avwiri and Agbalagba, 2007). The water samples were immediately acidified with $20 \mathrm{ml}$ $\pm 1 \mathrm{ml}$ of nitric acid per liter of sample collected to minimize the absorption of radioactivity into the walls of the containers [ISO, 9697 \& 9698: 1992a].The samples were then tightly covered and kept in the laboratory. For purposes of analysis the samples were slowly evaporated without boiling, down to a volume of $50 \mathrm{ml}$ at a furnace temperature of $60^{\circ} \mathrm{C}$. The residue was then transferred to a stainless-steel planchet, dried and allowed to equilibrate with ambient temperature and weighed. The counting time was 30000s while the screening technique is as reported by (Avwiri and Agbalagba, 2007) and in agreement with ISO, 9697 and 9698: $1992 b$ guidelines.

Counting Equipment: The gas-flow-proportional counter (Eurisys Measure- IN20) eight channel counter at the Material Laboratory, Centre for Energy Research and Training (CERT), Ahmadu Bello University (ABU), Zaria was used for the counting. Each counter channel has a window thickness of $450 \mu \mathrm{gcm}^{-3}$ and a diameter of $60 \mathrm{~mm}$. The chambers are covered with lead whose thickness can be varied. The detectors are operated within the radiation environment of $<101 \mu \mathrm{radh}^{-1}$. The system is connected to a microprocessor loaded with a spreadsheet programme (Quarttro-Pro) and graphic programme (Multiplan). The system can be operated at a bias voltage $(\sim 1100 \mathrm{~V}$ with P10 gas: argonmethane of $10 \%$ ) where only alpha particles are detected, referred to as 'alpha-only' mode

\section{${ }^{I}$ EZEKIEL O. AGBALAGBA; GREGORY O. AVWIRI; YEHUWDAH E. CHAD- UMOREN}


Detector Calibration: The alpha standard was ${ }^{239} \mathrm{Pu}$ with a half life of 24110years, while the beta standard was ${ }^{90} \mathrm{Sr}$ with a half life of 28 years. Their respective activities were calculated at the time of the calibration and are presented in Tables1 and 2 respectively. These standards were certified by CERCA LEA Laboratories in France with certification numbers CT 001/1285/001920-1927 and CT 1271/00/1778- 1783, respectively

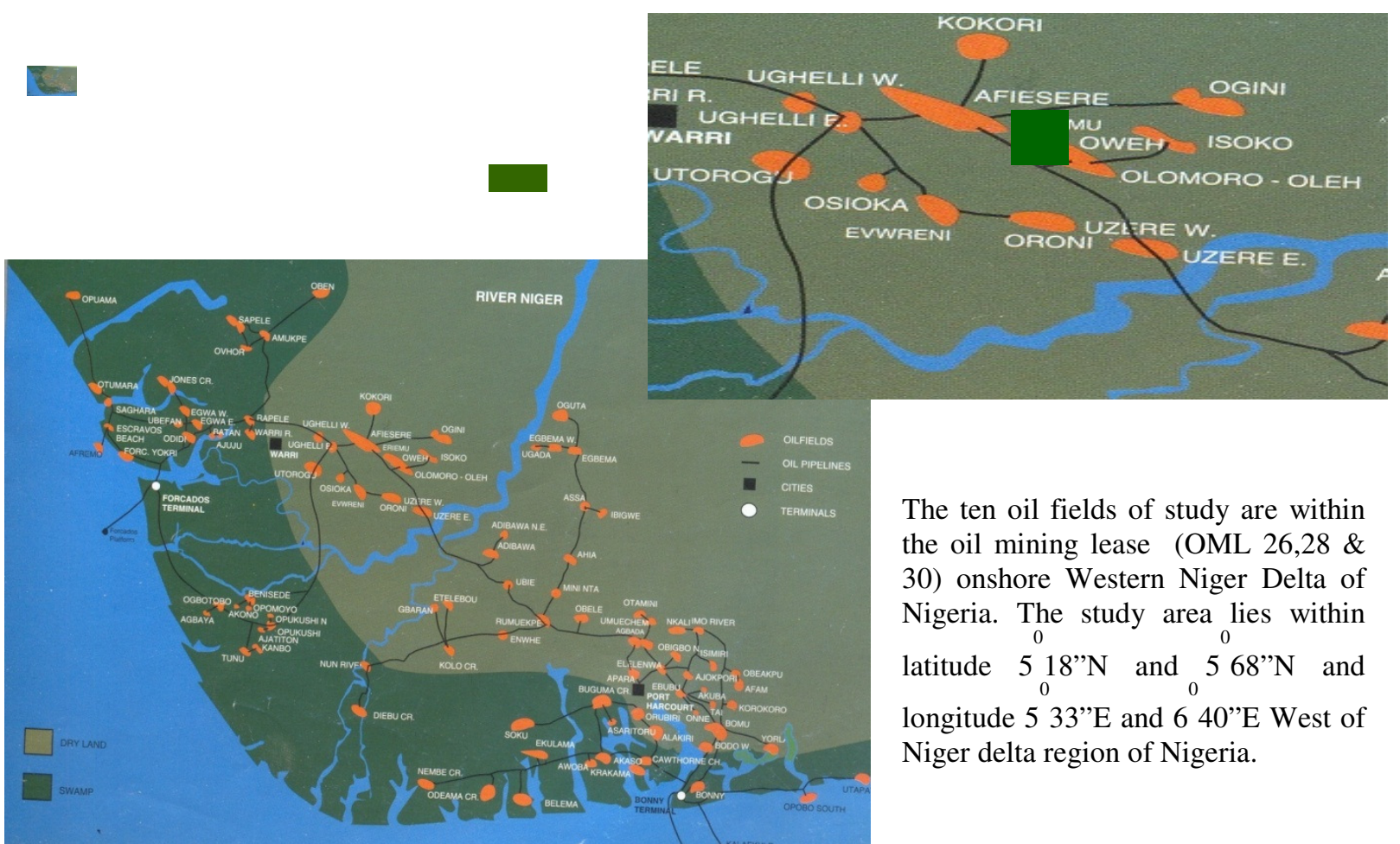

Fig 1: A map showing network of pipes of oil fields in onshore of the Niger Delta.

Source: SPDC, EIA, 2004).

Table1: The Alpha Standard Sources Serial Number and Activities at first Calibration and at the Moment.

\begin{tabular}{|l|l|l|}
\hline Serial Number & $\begin{array}{l}\text { Activity in } \\
(\mathbf{B q}) \text { at 29/11/2000 }\end{array}$ & $\begin{array}{l}\text { Activity in } \\
(\mathbf{B q}) \text { at 12/10/2010 }\end{array}$ \\
\hline EASB 20/50026 & 160.1 & 159.4 \\
\hline EASB 20/50050 & 170.3 & 170.0 \\
\hline EASB 20/50051 & 157.4 & 156.6 \\
\hline EASB 20/50052 & 133.3 & 133.0 \\
\hline EASB 20/50053 & 168.1 & 168.0 \\
\hline EASB 20/50054 & 185.5 & 185.1 \\
\hline EASB 20/50055 & 185.8 & 185.2 \\
\hline EASB 20/50056 & 168.3 & 168.0 \\
\hline
\end{tabular}

Plateau test was run with the manufacturer's calibration standards $\left({ }^{239} \mathrm{Pu}\right.$ and $\left.{ }^{90} \mathrm{Sr}\right)$ whose activities ranges from 133.29 to $185.51 \mathrm{~Bq}$ and 92.31 to $103.68 \mathrm{~Bq}$, respectively in all the three operating modes. This test was run for 1800 s for five cycles.
Table2: The Beta Standard Sources Serial Number and Activities at first Calibration and at the Moment.

\begin{tabular}{|l|l|l|}
\hline Serial Number & $\begin{array}{l}\text { Activity in } \\
(\mathbf{B q}) \text { at 22/11/2000 }\end{array}$ & $\begin{array}{l}\text { Activity in } \\
\text { Bq) } \text { at 16/2/2010 }\end{array}$ \\
\hline EASB 20/14529 & 118.5 & 86.5 \\
\hline EASB 20/14530 & 117.7 & 86.4 \\
\hline EASB 20/14531 & 106.9 & 77.7 \\
\hline EASB 20/14533 & 105.5 & 78.0 \\
\hline EASB 20/14535 & 113.1 & 82.8 \\
\hline EASB 20/14536 & 106.9 & 77.3 \\
\hline EASB 20/14537 & 106.4 & 77.9 \\
\hline EASB 20/14539 & 105.1 & 77.0 \\
\hline
\end{tabular}

The operational efficiencies of the eight channels of the counter were thus obtained as presented in Table 3.

\section{${ }^{1}$ EZEKIEL O. AGBALAGBA; GREGORY O. AVWIRI; YEHUWDAH E. CHAD- UMOREN}


Background radiation level detection :The background radioactivity counting procedure adopted in this study is as previously reported elsewhere (Onoja, et al., 2004a; Avwiri and Agbalagba, 2007, and Muhammad, et al., 2010). The results indicate reproducibility in all the six adopted channels of the counter. It also gives an average background radiation activity of $0.17 \mathrm{~Bq}$ for alpha in the alphaonly mode and $1.13 \mathrm{~Bq}$ for beta in the beta-only mode. These values are representative of the environment and could therefore be employed in the subsequent measurement of the water samples.

The annual effective equivalent dose to adults and infants estimated for the alpha activity in the water samples analyzed were carried out using standard dose equations (Fernandez et.al., 1992; Sajo-Bohus, et.al 1997 and USA-EPA, 2001).

Statistical Analysis:A bar chart of alpha and beta activities of the different water sources were compared with the WHO standard to verify if they are within regulatory limits. A linear correlation of alpha and beta activities in the different water sources was run to ascertain the relationship between them. This is to show if different radionuclides are responsible for gross alpha and gross beta activities in a sample.

\section{RESULTS AND DISCUSSION}

Table 3: Channel efficiency calibration results

\begin{tabular}{|l|l|l|l|}
\hline $\begin{array}{l}\text { Detector } \\
\text { No }\end{array}$ & $\begin{array}{l}\text { Alpha only, } \\
\boldsymbol{\alpha} \text { channel efficiency } \\
\mathbf{\%}\end{array}$ & $\begin{array}{l}\text { Beta }(+\boldsymbol{\alpha}) \\
\boldsymbol{\beta} \text { channel eff. } \\
\mathbf{\%}\end{array}$ & $\begin{array}{l}\boldsymbol{\alpha} / \boldsymbol{\beta} \\
\text { simultaneously } \\
\boldsymbol{\beta} \text { channel eff. } \\
\mathbf{\%}\end{array}$ \\
\hline 01 & 35.34 & 46.47 & 29.22 \\
\hline 02 & 35.85 & 35.39 & 19.79 \\
\hline 03 & 164.68 & 74.50 & 227.79 \\
\hline 04 & 36.87 & 38.79 & 23.25 \\
\hline 05 & 34.41 & 40.67 & 20.69 \\
\hline 06 & 34.74 & 42.94 & 23.44 \\
\hline 07 & 524.91 & 5908.45 & 536.30 \\
\hline 08 & 36.03 & 34.88 & 20.62 \\
\hline Average & $\mathbf{3 5 . 5 3}$ & $\mathbf{4 0 . 0 0}$ & $\mathbf{2 2 . 8 4}$ \\
\hline
\end{tabular}

- Exempted channels for the final counting.

The result of the detector efficiency calibration is presented in Table 3 . The results show that channels 3 and 7 have efficiency out of range, which may be as a result of previous use of the channels for contaminated samples. These channels were therefore not considered and were therefore not used for the counting of the samples.

Table 4: Alpha and Beta Activity Concentration for the Sampled Oil Field Water Sources

\begin{tabular}{|c|c|c|c|c|c|c|c|}
\hline \multirow{3}{*}{$\begin{array}{l}\mathbf{S} / \\
\mathbf{N}\end{array}$} & \multirow{3}{*}{$\begin{array}{l}\text { SAMPLED OIL } \\
\text { FIELD }\end{array}$} & \multicolumn{6}{|c|}{ WATER SAMPLE GROSS ACTIVITY CONCENTRATION (Bq/l) } \\
\hline & & \multicolumn{2}{|c|}{ Host Comm. Well Water } & \multicolumn{2}{|c|}{ Host Comm. Tap Water } & \multicolumn{2}{|c|}{ Field River Water } \\
\hline & & $\alpha$-activity & $\beta$-activity & $\alpha$-activity & $\beta$-activity & $\alpha$-activity & $\beta$-activity \\
\hline 1 & Uzere West\&East & $0.06 \pm 0.002$ & $11.9 \pm 0.1$ & $0.1 \pm 0.001$ & $7.7 \pm 0.04$ & $35.1 \pm 1.1$ & $151.2 \pm 1.8$ \\
\hline 2 & Olomoro/Oleh & $0.7 \pm 0.01$ & $5.9 \pm 0.03$ & $0.05 \pm 0.002$ & $1.1 \pm 0.05$ & $1.7 \pm 0.02$ & $15.8 \pm 0.03$ \\
\hline 3 & Oweh & $0.4 \pm 0.01$ & $1.6 \pm 0.02$ & $0.07 \pm 0.002$ & $16.2 \pm 0.1$ & $0.02 \pm 0.001$ & $0.7 \pm 0.03$ \\
\hline 4 & Evwreni & $0.06 \pm 0.003$ & $1.1 \pm 0.04$ & $0.02 \pm 0.002$ & $54.7 \pm 1.3$ & $1.2 \pm 0.05$ & $46.7 \pm 0.2$ \\
\hline 5 & Eriemu & $0.1 \pm 0.002$ & $1.2 \pm 0.04$ & $0.01 \pm 0.003$ & $0.9 \pm 0.03$ & $0.02 \pm 0.001$ & $3.0 \pm 0.1$ \\
\hline 6 & Kokori & $0.02 \pm 0.002$ & $7.4 \pm 0.1$ & $0.1 \pm 0.003$ & $0.6 \pm 0.2$ & $1.4 \pm 0.1$ & $135.9 \pm 6.7$ \\
\hline 7 & Afiesere & $0.02 \pm 0.001$ & $5.1 \pm 0.1$ & $0.1 \pm 0.002$ & $1.0 \pm 0.01$ & $0.04 \pm 0.002$ & $3.2 \pm 0.1$ \\
\hline 8 & Ughelli East & $0.03 \pm 0.001$ & $11.1 \pm 0.2$ & $0.02 \pm 0.004$ & $2.3 \pm 0.04$ & $0.05 \pm 0.001$ & $5.8 \pm 0.1$ \\
\hline 9 & Ughelli West & $0.01 \pm 0.002$ & $1.3 \pm 0.02$ & $0.5 \pm 0.01$ & $1.2 \pm 0.01$ & $0.2 \pm 0.02$ & $31.0 \pm 0.1$ \\
\hline 10 & Otorogu & $0.1 \pm 0.003$ & $13.2 \pm 0.1$ & $0.03 \pm 0.001$ & $0.7 \pm 0.05$ & $0.05 \pm 0.001$ & $7.8 \pm 0.1$ \\
\hline \multicolumn{2}{|c|}{ AVERAGE } & $0.15 \pm 0.003$ & $6.0 \pm 0.1$ & $0.1 \pm 0.003$ & $8.6 \pm 0.2$ & $4.1 \pm 0.1$ & $40.1 \pm 0.9$ \\
\hline \multicolumn{2}{|c|}{ WHO limit (Bq/l) } & 0.1 & 1.0 & 0.1 & 1.0 & 0.1 & 1.0 \\
\hline
\end{tabular}

Three sources of water were considered for the water sample analyses viz. well, tap and river (Table 4).

Well water: Alpha activity concentration in the well water samples ranges from $0.01 \pm 0.002 \mathrm{Bql}^{-1}$ for Ekakpamre well water in Ughelli West oil and gas field to $0.7 \pm 0.01 \mathrm{Bql}^{-1}$ for Olomoro well water with a mean of $0.15 \pm 0.003 \mathrm{Bql}^{-1}$. Beta activity concentration ranges from $1.1 \pm 0.04 \mathrm{Bql}^{-1}$ for Evwreni well water to $13.2 \pm 0.1 \mathrm{Bql}^{-1}$ for Otujeremi community well water in Otorogu oil and gas field with a mean value of $6.0 \pm 0.1 \mathrm{Bql}^{-1}$.

\section{${ }^{1}$ EZEKIEL O. AGBALAGBA; GREGORY O. AVWIRI; YEHUWDAH E. CHAD- UMOREN}

The alpha activity concentrations in all the well water samples examined are within the practical screening level of $0.1 \mathrm{Bql}^{-1}$ except for the samples from wells in Olomoro and Oweh communities. The relatively low alpha activity may be attributed to low natural radionuclide content associated with the Niger delta underlying sedimentary rocks (Taiwo and Akalia, 2009). It should be pointed out that oil and gas activity appears to play some role in the radionuclide content of the surveyed water samples. It is observed 
that well water samples from earth wells except at Olomoro, Evwreni and Oweh community of concrete wells reveals that the concrete or rig wells radionuclide concentration may have been enhanced from the materials used in the rigs construction as values from these well are relatively higher. The average value is above the $10.8-73.4 \mathrm{mBql}^{-1}$ reported in Batman, Turkey and $0.2-15 \mathrm{mBql}^{-1}$ reported in the Eastern Black sea region also in Turkey (Damla, et al., 2006 and Damla, et al., 2009). They are however lower than the alpha average of $0.6 \mathrm{Bql}^{-1}$ reported in 1997). The average alpha activity value of $6.35 \mathrm{Bql}^{-1}$ reported in Kaduna well water (Onoja, 2004b) is $97.75 \%$ higher than the values obtained in this well water studied.

The beta activity values reported for well water are above the WHO $1.0 \mathrm{Bql}^{-1}$ recommended practical screening level for drinking water (WHO, 2003). This indicates the presence of pollutants of anthropogenic origins as screening for beta activities in the environment is screening for artificial or anthropogenic radionuclides. Such pollutants, as in the Niger delta region, include gas flare pollutants transported by air to water bodies and other radioactive polluting agents.

Tap water: For the public tap water, the alpha activity concentration ranges from $0.01 \pm 0.003 \mathrm{Bql}^{-1}$ for the Erhoike community public tap in Eriemu oil field to $0.5 \pm 0.01 \mathrm{Bql}^{-1}$ for Ekakpamre community tap water in Ughelli West oil and gas field with a mean alpha activity value of $0.1 \pm 0.003 \mathrm{Bql}^{-1}$, while the beta activity ranges from $0.7 \pm 0.1 \mathrm{Bql}^{-1}$ for Otujeremi in Otorogu oil field to $54.7 \pm 1.3 \mathrm{Bql}^{-1}$ for Evwreni community oil field with a mean value of $8.9 \pm 0.2 \mathrm{Bql}^{-}$ 1 .

The average alpha activity for tap water obtained in this present study is $99.63 \%$ below the $27.8 \mathrm{Bql}^{-1}$ obtained in Belgium drinking water (Onoja, 2004b). The low alpha activity concentrations for tap water further confirm the low natural radionuclide activity of the underlying rocks of the region. Though there are spotted areas of elevation indicating the presence of pollutants, the trend for the study area is generally within the practical screening level of $0.1 \mathrm{Bql}^{-1}$ for alpha activity in water.

The high beta emitter activity observed in Oweh community tap water $\left(16.2 \pm 0.1 \mathrm{Bql}^{-1}\right)$ and Evwreni tap water $\left(54.7 \pm 1.3 \mathrm{Bql}^{-1}\right)$ may be attributed to longburied anthropogenic materials within these areas or Venezuela population well water (Sojo-Bohus, et al.,

may be as a result of accidental underground pollutant seepage into the environment. However, detailed specific activity study is required.

The average beta activity obtained for tap water in the host communities is $7.6 \mathrm{Bql}^{-1}$ higher than the maximum screening level of $1.0 \mathrm{Bql}^{-1}$ recommended for drinking water by WHO and CEC (WHO, 2003) and is $11.4 \%$ of the $7.5 \mathrm{Bql}^{-1}$ value reported for tap water in Kaduna (Onoja, 2004; Juliet, 2006) and is $12 \%$ of maximum reported value of $72.2 \mathrm{Bql}^{-1}$ in Belgium (Onoja, 2004b). And in general, the values are higher than those reported in tap water from the Eastern Black sea region of Turkey (Damla, et al., 2006).

If we compare our results for well and tap water with values obtained in other countries, it is observed that our values are generally higher in terms of tap water in Iran (Sohrabi et al., 1998), bottled water in Spain (Duenas et al., 1997) and in Mexico (Davila Rangel et al., 2002), and ground water in Western Anatolia, Turkey (Akyil et al., 1996), Rio Gande do Norte,

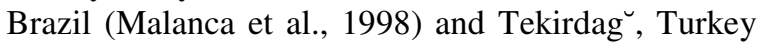
(Yarar and Kam, 2005).

River water: In Table 4, results from the oil field river water analyzed shows that alpha activity varies from $0.02 \pm 0.001 \mathrm{Bql}^{-1}$ in Kokori oil field to $35.1 \pm 1.1 \beta \mathrm{ql}^{-1}$ in Uzere East and West oil spilled polluted river water with a mean value of $4.1 \pm 0.1 \mathrm{Bql}^{-}$ ${ }^{1}$, while the beta activity ranges from $0.7 \pm 0.03 \mathrm{Bql}^{-1}$ in Oweh oil field stream water to $151.2 \pm 1.8 \mathrm{Bql}^{-1}$ in the Uzere East and West oil spilled polluted river water with a mean value of $40.1 \pm 0.9 \mathrm{Bql}^{-1}$. The mean alpha activity for river water $\left(4.1 \pm 0.1 \mathrm{Bql}^{-1}\right)$ is $4.08 \mathrm{Bql}^{-1}$ higher than the $0.02 \mathrm{Bql}^{-1}$ reported for Woronara river water, and is $3.95 \mathrm{Bql}^{-1}$ higher than the $0.154 \mathrm{Bql}^{-1}$ value reported in Mills Creek in Australia (Avwiri and Agbalagba). It also exceeds the Australia Causeway River water alpha activity by $4.10 \mathrm{Bql}^{-1}$ (Onoja, 2004b), Woronora river Down Stream (saline) by $0.52 \mathrm{Bql}^{-1}$, Finland Lake by $4.11 \mathrm{Bql}^{-1}$, Baltic sea by $4.12 \mathrm{Bql}^{-1}$ (Szabo, et al., 1998; Avwiri and Agbalagba, 2007). The average alpha activity also exceed the average alpha activity of river Kaduna (0.1173 $\mathrm{Bql}^{-1}$ ) by $3.98 \mathrm{Bql}^{-1}$ (Juliet, 2006). However, the value is lower than the mean alpha activity value reported earlier for Okpare Creek (Avwiri and Agbalagba, 2007) and is also lower than the alpha activity value of $6.7 \pm 0.074 \mathrm{Bql}^{-1}$ reported for Opa River irrigation farmland (Fassasi et al., 1999).

${ }^{1}$ EZEKIEL O. AGBALAGBA; GREGORY O. AVWIRI; YEHUWDAH E. CHADUMOREN 
A comparison of the measured alpha activity for the three water sources with WHO standard shows that average well and river water activity concentrations exceed the WHO level while tap water average alpha activity concentration is within the WHO $0.1 \mathrm{Bql}^{-1}$ recommended level. The relatively high alpha activity recorded in some of the rivers investigated in this work can be attributed to oil spillage and incomplete remediation of oil spillage.

The results obtained for mean beta activity is 39.914 $\mathrm{Bql}^{-1}$ higher than the $0.186 \mathrm{Bql}^{-1}$ recorded at Mills Creek, Australia; 39.666 $\mathrm{Bql}^{-1}$ higher than the average beta activity concentration recorded at river Kaduna and $39.606 \mathrm{Bql}^{-1}$ higher than the value recorded at Causeway River in Australia (Onoja, 2004b). The average beta activity of the water sources surveyed in this work is far above the values reported for the Baltic Sea, Finland lakes, Okpare Creek and Venezuela public drinking water (Szabo, et al., 1998; Sajo-Bohus, 1997 and Avwiri and Agbalagba, 2007).

Table 4 shows the comparison of the beta activity concentration of the three water sources in the oil fields with the WHO recommended maximum level, the result revealed that the average value for all the three sources of water examined exceeded the WHO maximum level of $1.0 \mathrm{Bql}^{-1}$. The observed high beta activity in almost all the river water samples shows that the river water in these oil fields have been polluted radiologically. This is attributed to the frequent oil spillage into these water bodies, surface run-off due to erosion into these rivers from oil spill land, top soil containing high concentration of ${ }^{40} \mathrm{~K}$ may have also enhanced the level of radionuclides in the river water. The hydrological process whereby polluted air are condensed in the atmosphere and precipitate back to the river water as acid rain may have also enhanced the radionuclide level in the study area. The high level of beta activities observed at Uzere east and west oil and gas field river, Evwreni oil field river, Ughelli west oil field stream, Otorogu oil and gas field river water sample and Oweh oil field stream are all traceable to present and recovered oil spilled polluted water. This indicates that crude oil and gas enhance the level of radioactivity in the oil field environment. Also, the average beta activity values obtained in the river water sources examined are well above the $1.0 \mathrm{Bql}^{-1}$ practical screening level of radioactivity in drinking water recommended by CEC-FAO and WHO (WHO, 2003).

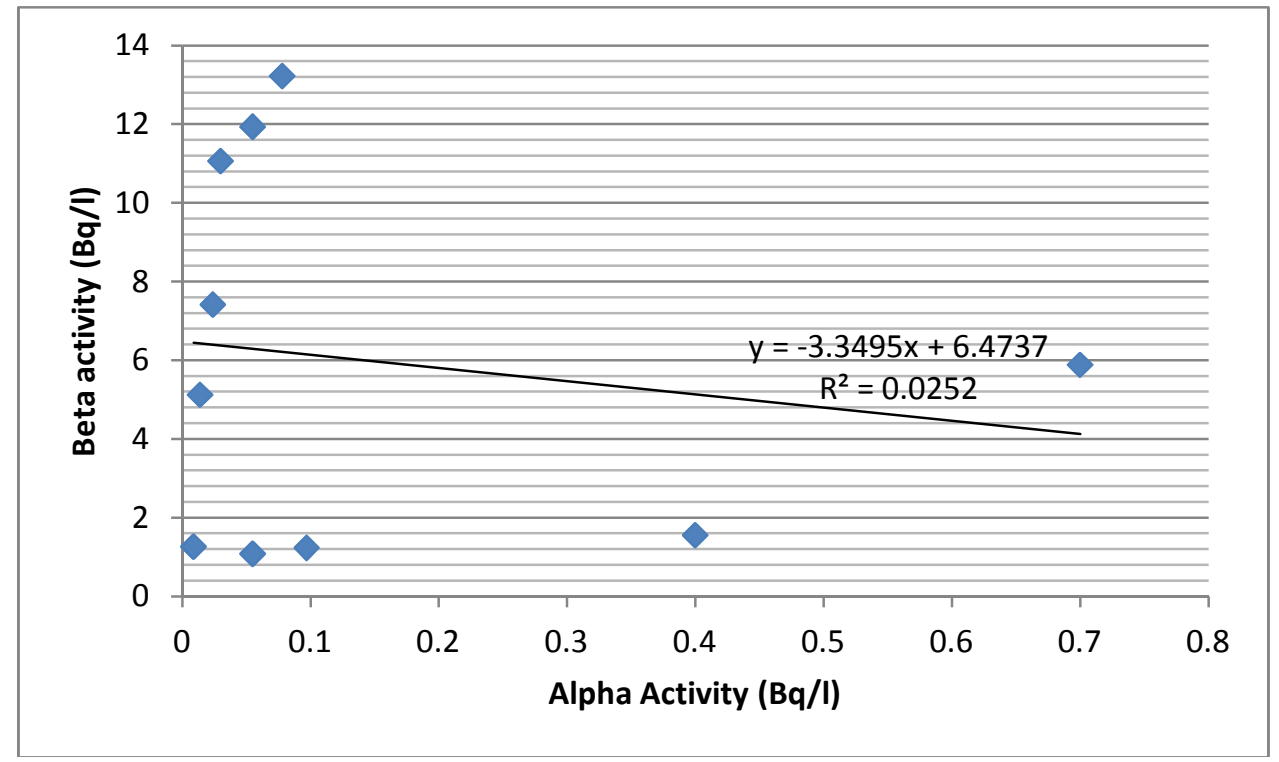

Fig 2: Correlation of Gross Alpha and Beta Activity in Well Water 


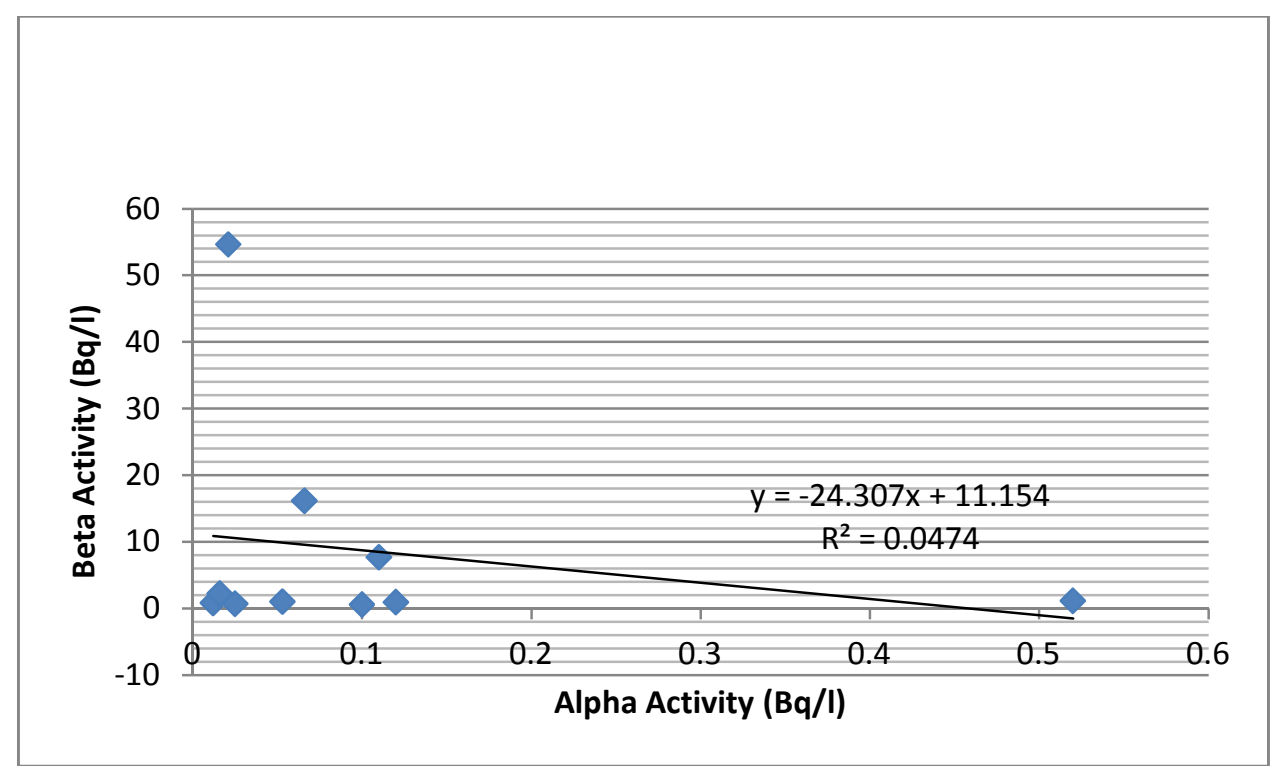

Fig 3: Correlation of Gross Alpha and Beta Activity in Tap Water

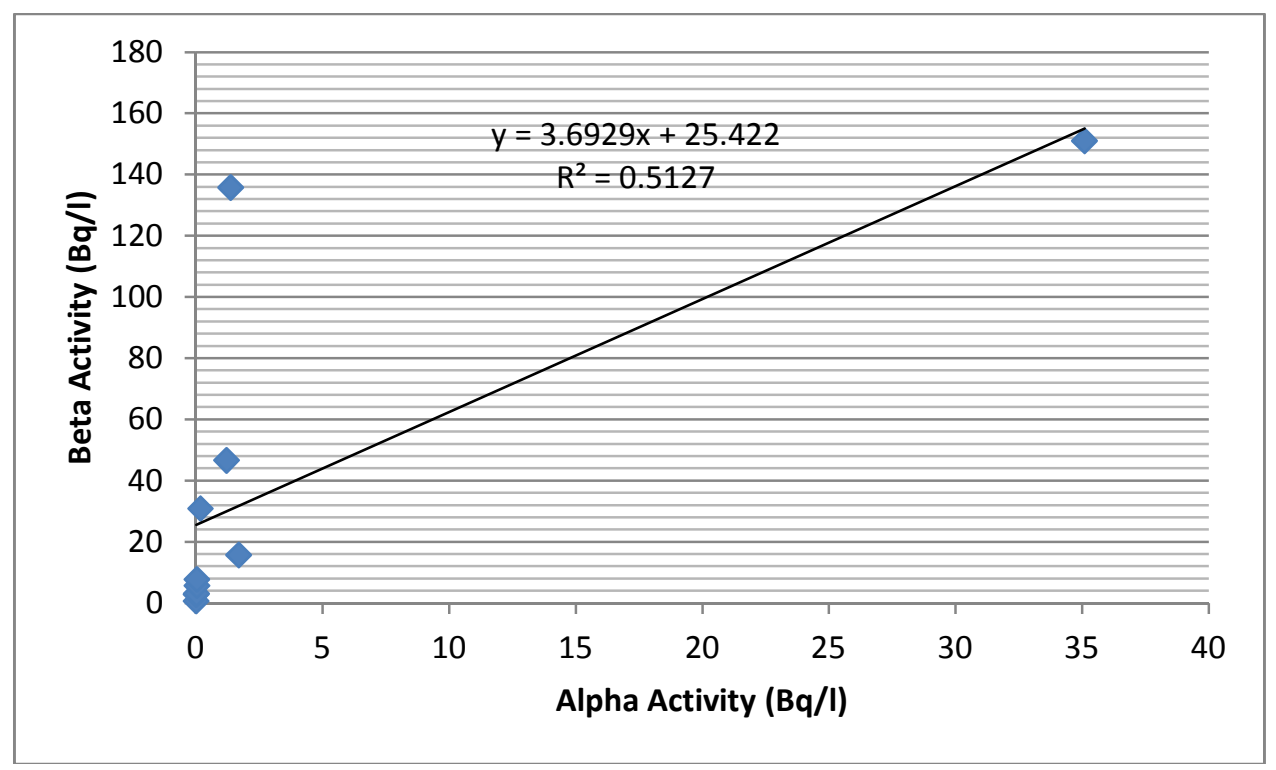

Fig 4: Correlation of Gross Alpha and Beta Activity in River Water

Figures 2, 3 and 4 show the linear correlation of alpha and beta concentration in the water sources. This is to verify if the same radionuclides are responsible for alpha and beta activities in the water samples. The results show a poor correlation in well and tap water with regression values of 0.025 and 0.047 respectively, while there is significant relationship (correlation) in the river water with a regression value of 0.512 . These show that different radionuclides are responsible for the alpha and beta activities in the water samples. 
Table 5: Estimated effective equivalent dose intake for adults and infants from gross alpha activity in the studied well water

\begin{tabular}{|l|l|l|l|l|l|}
\hline S/N & \multirow{2}{*}{$\begin{array}{l}\text { Oil Field Host } \\
\text { Comm. }\end{array}$} & Sample Code & \multicolumn{2}{l|}{ Effective Equivalent dose $\left(\boldsymbol{\mu S v y r} \mathbf{~}^{-\mathbf{1}}\right)$} \\
\cline { 4 - 6 } & & & $\boldsymbol{\alpha}$-Activity $\left(\boldsymbol{\beta q I} \mathbf{~}^{-\mathbf{1}}\right)$ & $\mathbf{D R}_{\mathbf{W}}(\mathbf{A d u l t})$ & $\mathbf{D R}_{\mathbf{W}}($ Infant $)$ \\
\hline 1 & Uzere & SUZP & $0.08 \pm 0.003$ & $40.8 \pm 1.4$ & $11.2 \pm 0.4$ \\
\hline 2 & Olomoro & SOLP & $0.06 \pm 0.002$ & $2.8 \pm 0.8$ & $7.9 \pm 0.2$ \\
\hline 3 & Oweh & SOWP & $0.7 \pm 0.01$ & $365.9 \pm 4.2$ & $100.3 \pm 1.2$ \\
\hline 4 & Evwreni & SEVP & $0.4 \pm 0.01$ & $209.1 \pm 6.3$ & $57.3 \pm 1.7$ \\
\hline 5 & Gana & SERP & $0.06 \pm 0.003$ & $28.8 \pm 1.4$ & $7.9 \pm 0.4$ \\
\hline 6 & Erhoike & SKOP & $0.02 \pm 0.002$ & $12.5 \pm 0.9$ & $3.4 \pm 0.3$ \\
\hline 7 & Emeragha & SAFP & $0.1 \pm 0.001$ & $50.7 \pm 0.7$ & $13.9 \pm 0.2$ \\
\hline 8 & Eruemikohwarien & SUWP & $0.01 \pm 0.001$ & $7.3 \pm 0.6$ & $0.004 \pm 0.2$ \\
\hline 9 & Ekakpamre & SUEP & $0.03 \pm 0.001$ & $15.7 \pm 0.6$ & $4.3 \pm 0.2$ \\
\hline 10 & Otujeremi & SOTP & $0.01 \pm 0.002$ & $4.7 \pm 0.9$ & $1.3 \pm 0.2$ \\
\hline MEAN & & $\mathbf{0 . 1 5} \pm \mathbf{0 . 0 0 3}$ & $\mathbf{7 6 . 4} \pm \mathbf{1 . 8}$ & $\mathbf{2 0 . 9} \pm \mathbf{0 . 5}$ \\
\hline
\end{tabular}

Table 6: Estimated Effective Equivalent Dose Intake For Adults and Infants From Gross Alpha Activity in the Studied Tap Water Samples.

\begin{tabular}{|l|l|l|l|l|l|}
\hline S/N & Oil Field Host Comm. & Sample Code & $\boldsymbol{\alpha}$-Activity $(\boldsymbol{\beta q} / \mathbf{l})$ & \multicolumn{2}{|l|}{ Effective Equivalent Dose $\left(\boldsymbol{\mu S v y r} \mathbf{S v}^{-\mathbf{1}}\right)$} \\
\cline { 5 - 6 } & & & & $\mathbf{D R}_{\mathbf{W}}($ Adult $)$ & $\mathbf{D R}_{\mathbf{W}}\left(\right.$ Infant $^{\prime}$ \\
\hline 1 & Uzere & SUZP & $0.1 \pm 0.001$ & $57.9 \pm 0.5$ & $15.8 \pm 0.1$ \\
\hline 2 & Olomoro & SOLP & $0.05 \pm 0.002$ & $27.7 \pm 0.9$ & $7.6 \pm 0.2$ \\
\hline 3 & Oweh & SOWP & $0.07 \pm 0.002$ & $34.5 \pm 0.05$ & $9.45 \pm 0.3$ \\
\hline 4 & Evwreni & SEVP & $0.02 \pm 0.002$ & $11.0 \pm 1.1$ & $3.01 \pm 0.3$ \\
\hline 5 & Gana & SERP & $0.01 \pm 0.0003$ & $6.2 \pm 0.2$ & $1.7 \pm 0.04$ \\
\hline 6 & Erhoike & SKOP & $0.1 \pm 0.003$ & $52.3 \pm 1.7$ & $14.3 \pm 0.6$ \\
\hline 7 & Emeragha & SAFP & $0.1 \pm 0.002$ & $62.7 \pm 1.1$ & $17.2 \pm 0.3$ \\
\hline 8 & Eruemukohwarie & SUWP & $0.02 \pm 0.004$ & $8.4 \pm 2.1$ & $2.3 \pm 0.6$ \\
\hline 9 & Ekakpamre & SUEP & $0.5 \pm 0.01$ & $271.8 \pm 4.2$ & $74.5 \pm 1.2$ \\
\hline 10 & Otujeremi & SOTP & $0.03 \pm 0.001$ & $13.1 \pm 0.6$ & $3.6 \pm 0.2$ \\
\hline \multicolumn{2}{|l|}{ MEAN } & & $\mathbf{0 . 1} \pm \mathbf{0 . 0 0 3}$ & $\mathbf{5 4 . 6} \pm \mathbf{1 . 3}$ & $\mathbf{1 4 . \pm 0 . 4}$ \\
\hline
\end{tabular}

Table 7: Estimated Effective Equivalent Dose Intake for Adults and Infants From Gross Alpha Activity in the Studied Oil Field River Water Samples.

\begin{tabular}{|l|l|l|l|l|}
\hline $\mathbf{S} / \mathbf{N}$ & \multirow{2}{*}{ Oil Field } & $\boldsymbol{\alpha}$-Activity $(\boldsymbol{\beta q} / \mathbf{l})$ & \multicolumn{3}{|l|}{ Effective Equivalent Dose $\left(\boldsymbol{\mu S v y r} \mathbf{S}^{-\mathbf{1}}\right)$} \\
\cline { 3 - 5 } & & & $\mathbf{D R}_{\mathbf{W}}(\mathbf{A d u l t})$ & $\mathbf{D R}_{\mathbf{W}}(\mathbf{I n f a n t})$ \\
\hline 1 & Uzere E/W & $35.1 \pm 1.1$ & $18346 \pm 587$ & $5026 \pm 161$ \\
\hline 2 & Olomoro/Oleh & $1.7 \pm 0.02$ & $888.6 \pm 9.4$ & $243.4 \pm 2.6$ \\
\hline 3 & Oweh & $0.02 \pm 0.001$ & $9.4 \pm 0.6$ & $2.6 \pm 0.2$ \\
\hline 4 & Evwreni & $1.2 \pm 0.1$ & $515.7 \pm 0.6$ & $174.7 \pm 6.6$ \\
\hline 5 & Eriemu & $1.4 \pm 0.1$ & $721.3 \pm 64.8$ & $197.6 \pm 17.8$ \\
\hline 6 & Kokori & $0.02 \pm 0.001$ & $7.3 \pm 0.7$ & $2.005 \pm 0.2$ \\
\hline 7 & Afiesere & $0.04 \pm 0.002$ & $19.3 \pm 0.9$ & $5.3 \pm 0.2$ \\
\hline 8 & Ughelli East & $0.05 \pm 0.001$ & $27.2 \pm 0.7$ & $7.5 \pm 0.2$ \\
\hline 9 & Ughelli West & $0.2 \pm 0.02$ & $622.0 \pm \pm 12.5$ & $170.4 \pm 3.4$ \\
\hline 10 & Otorogu & $0.05 \pm 0.001$ & $25.6 \pm 0.5$ & $7.0 \pm 0.1$ \\
\hline & MEAN & $\mathbf{4 . 1} \pm \mathbf{0 . 1}$ & $\mathbf{2 1 1 8 . 2 \pm 7 0 . 2}$ & $\mathbf{5 8 3 . 7} \pm \mathbf{1 9 . 2}$ \\
\hline
\end{tabular}

To quantify the dose intake to human for the consumption of the water from these sources and to quantify the health hazards associated with such consumption, the effective equivalent dose to man is estimated. This estimation gives a good approximation of the effective dose rate to our bodies and is a function of the quantity of the water consumed per year. Two distinct classes of people with estimated quantity of water consumption rate per year have been reported: 730 litres for adults and 200 litres for infants (Fernandez, et al., 1992; Torrealba, et al., 1993 and Sajo-Bohus et al., 1997). The effective equivalent dose intake for adults and infants from gross alpha emitters in the studied water samples were calculated using equation 1 . Tables 5 to 7 show the estimated effective equivalent dose for the well water, tap water and river water samples respectively. The effective equivalent dose for well 
water (Table 5) ranges from $4.7 \pm 0.9 \mu \mathrm{Svy}^{-1}$ to $365.9 \pm 4.2 \mathrm{MSvy}^{-1}$ with a mean value of $76.4 \pm 1.8 \mu \mathrm{Svy}^{-1}$ for adults, while it ranges from $1.3 \pm 0.3 \mu \mathrm{Svy}^{-1}$ to $100.2 \pm 1.2 \mu \mathrm{Svy}^{-1}$ with a mean value of $20.9 \pm 0.5 \mu \mathrm{Svy}^{-1}$ for infants. These values are well within the $0.1 \mathrm{mSvy}^{-1}$ reference dose level (RDL) recommended limit for the public (ICRP, 1991). We observe also that the estimated effective equivalent dose values obtained in this work are lower than the naturally received doses of $1.55 \mathrm{mSvy}^{-1}$ due to environmental gamma and $1.75 \mathrm{mSvy}^{-1}$ due to environmental radon (Torrealba, et al., 1993).

In Table 6, the effective equivalent dose intake by adults for tap water consumption ranges from $6.2 \pm 0.2 \mu \mathrm{Svy}^{-1}$ to $271.8 \pm 4.2 \mu \mathrm{Svy}^{-1}$ with a mean value of $54.6 \pm 1.3 \mu \mathrm{Svy}^{-1}$ while for infants the value ranges from $1.7 \pm 0.04 \mu \mathrm{Svy}^{-1}$ to $74.5 \pm 1.2 \mu \mathrm{Svy}^{-1}$ with a mean value of $14.9 \pm 0.4 \mu \mathrm{Svy}^{-1}$. Again, these values are well within the ICRP, 1991 recommended level for the public and are lower than the naturally received doses due to environmental gamma and environmental radon (Torrealba et.al., 1993). Table 7 shows the effective equivalent dose intake for adults and infants from alpha emitters in the river water. Adult values range from $7.3 \pm 0.7 \mu \mathrm{Svy}^{-1}$ to $18,346 \pm 587 \mu \mathrm{Svy}^{-1}$ with a mean value of $2118 \pm 70 \mu \mathrm{Svy}^{-1}$ while it ranges from $2.0 \pm 0.2 \mu \mathrm{Svy}^{-1}$ to $5026 \pm 161 \mu \mathrm{Svy}^{-1}$ with a mean value of $584 \pm 19.2 \mu \mathrm{Svy}^{-1}$ for infants. The results show that the dose intake by adults and infants due to the consumption of Uzere river water is far above the maximum recommended value for adults and infants and thus, can be classified as highly polluted water. The values obtained for the river water from Olomoro/Oleh , Evwreni, Eriemu and Ughelli west oil fields are relatively high and may be considered contaminated. The average value for river water intake for adult per annum is above the ICRP recommended limit, thus the water from these rivers are radiologically polluted and their consumption may result in health hazards for members of the host communities consuming it.

A comparison of the level of dose intake by both infants and adults from the three water sources show that the dose intake from river water $>$ dose intake from well water $>$ dose intake from tap water.

Conclusion:This study evaluated the gross alpha and beta radionuclide activities and also estimated the radiation dose intake in surface and ground water in an environment with oil exploration activities. Gross alpha and beta emitter activities in the wells, taps and river waters vary in quantity within oil fields and from one oil field to another. The estimated dose intake for adults and infants also shows wide variation between the water sources. The high doses received in some areas can be attributed to the effluent discharge and oil spillage into the river water and incomplete remediation of oil spillage, the underground water distribution/flow processes which may have enhanced the radionuclide concentration levels in the water.

We conclude that the heterogeneity observed in the radionuclide distribution in the water sources is due to the water transportation process, precipitation of obnoxious materials released into the atmosphere by oil and gas exploitation activities and effluent discharge of various magnitudes in the oil fields. Consequently, this study indicates that the investigated water sources have been contaminated radiologically. We therefore recommend that the water from these sources be treated for radioactivity before consumption. Or preferably, alternative water supply could be provided for members of the host communities.

\section{REFERENCES}

Akyil, S., F.S. Erees and S. Olmez, 1996. Gross alpha;-particle activities in the ground waters in Western Anatolia. Appl. Radiat. Isot., 47: 709-711.

Avwiri, G.O and Agbalagba, E.O., 2007. Survey of gross alpha and gross beta radionuclide activity in Okpare-Creek Delta State Nigeria. J. Appl. Sci. 7(22): 3542-3546.

Avwiri,G.O., Agbalagba, E.O. and P.I. Enyinna, 2008. Radioactivity concentration and distribution in River Forcados Delta state, Nigeria. Scientia Africana 7(1): 128-135

Chad-Umoren, Y. E (2012): Ionizing Radiation Profile of the Hydrocarbon Belt of Nigeria in Mitsuru Nenoi (Editor): Current Topics in Ionizing Radiation Research, InTech Publications, Janeza Trdine 9, 51000 Rijeka, Croatia. ISBN 978-953-51-0196-3

Damla, N., U. Cevik, G. Karahan and A.I. Kobya, 2006. Gross alpha and beta activities in tap water in Eastern Black Sea region of Turkey. Chemosphere 62: 957-960

Damla, N., U. Cevik, G. Karahan, A.I. Kobya, M. Kocak and U. Isik, 2009. Determination of gross 
alpha and beta activities in water from Batman, Turkey. Desalination, 244: 208-214.

Davila Rangel, J.I., H. Lopez del Rio, G.F. Mireles, L.L.Q. Torres, M.L. Vilalba, L.C. Sujo and M.E.M. Cabrera, 2002. Radioactivity in bottled waters sold in Mexico. Appl. Radiat. Isot., 56: 931-936.

Duenas, C., M.C. Fernandez, E. Liger and J. Carretero, 1997. Natural radioactivity levels in bottled water in Spain. Water Res., 31: 1919-1924

El-Gamal, A., Nasr, S. and El-Taher, A., 2007. Study of the spatial distribution of natural radioactivity in Upper Egypt Nile River Sediments. Radiation Measurement 42: 457-465.

Fasasi, M.K., Tchokossa, P., Ojo, J.O. and Balogun, F.A., 1999. Occurrence of natural radionuclide and fallout Cesium-137 in dry season agricultural land of south-western Nigeria. J. Radioanlyt. Nucl. Chem., 240. 949-952.

Fernandez, J.F., J.C. Lozano and J.M.G. Gomez, 1992. Natural radionuclides in ground water in Western Spain. Radiat. Protect. Dosim., 45: $227-$ 229.

IAEA, 1996. International Basic Safety Standards for Protection Against Ionizing Radiation and for the Safety of Radiation Sources. International Atomic Energy Agency, Vienna.

ICRP, 1991. The 1990 Recommendations of the International Commission on Radiological Protection, Volume 21-23. Elsevier Health Sciences, USA

Salih, M.M.I., H.B.L. Pettersson and E. Lund, 2002. Uranium and thorium series radionuclides in drinking water from drilled bedrock wells: Correlation to geology and bedrock radioactivity and dose estimation. Radiat. Protect. Dosim., 102: $249-258$

ISO, 1992a. Water Quality-Measurement of Gross \&alpha; Activity in Non-Saline Water-Thick Source Method. International Organization for Standardization, London.

ISO, 1992b. Water Quality-Measurement of Gross \&beta; Activity in Non-Saline Water-Thick
Source Method. International Organization for Standardization, London.

Juliet, N.M., 2006. Gross alpha and beta radioactivity in Kaduna River, M.sc. thesis, ABU, Zaria

Laogun, A.A., N.O Ajayi and S.A. Agaja, 2006. Variation in wellhead gamma radiation levels at the Nigeria Petroleum development company oil field, Ologbo Ede State, Nigeria. Nig. J. Phys, 18(1):135-140.

Malanca, A., M. Repetti and H.R. Macedo, 1998. Gross alpha and beta-activities in surface and ground water of Rio Grando do Norte, Brazil. Appl. Radiat. Isot., 49: 893-898.

Muhammad, B.G., M.S. Jaafar and T.C. Akpa, 2010. A survey of gross alpha and beta activity concentrations in groundwater from Katsina area of Northern Nigeria. Radiat. Prot. Dosim., 142: 127-133.

Onoja, R.A., Akpa, T.C., Malam, S.P. and Ibeanu, I.G.E., 2004. Characteristics of the gross alpha/beta counter in the center for energy research and training. Zaria. Nig. J. Phys. 16:1318.

Onoja, R.A., 2004. Survey of Gross alpha and beta radioactivity in well water from Zaria Area M.Sc. Thesis, ABU Zaria.

Singh, P., N.P.S. Rana, A. Azam, A.H. Naqvi and D.S. Srivastava, 1996. Levels of Uranium in waters from some Indian cities determined by fission track analysis. Radiat. Meas., 26: 683687.

Pujol, L. and J.A. Sanchez-Cabeza, 2000. Natural and artificial radioactivity in surface waters of the Ebro River basin (North-east Spain). J. Environ. Radioact., 51: 181-210.

Sajo-Bohus, L., J. Gomez, T. Capote, E.D. Greaves, O. Herrera, V. Salazer and A. Smith, 1997. Gross \&alpha; radioactivity of drinking water in Venezuela. J. Environ. Radioact., 35: 305-312.

Sohrabi, M., N. Alirezazadeh and H.T. Ahmadi, 1998. A survey of $222 \mathrm{Rn}$ concentrations in domestic water supplies of Iran. Health Phys., 75: 417-421. 
Shell Petroleum Development Company,(SPDC, EIA) 2004. Environmental impact assessment $\mathrm{f}$ Afiesere, Eriemu, Repele and Uzere for oil field development. Scooping workshop for EIA process, SPDC West, Warri Delta State, Nigeria. May 2004; pg 2-6.

Szabo, Z., DePaul, V.T., and Ponsa, B., 1998. Decrease in gross alpha- particle activity in water samples with time after collection from the Kirkwood- Cohansay aquifer system in south New Jersey: Implications for safe drinking water regulations [Abstract]; $63^{\text {rd }}$ annual meeting of New Jersey section of America water Works association. Atlantic city, New jersey.

Taiwo, B.A. and T.C. Akalia, 2009. Spatial variation in groundwater geochemistry and water quality index in Port Harcourt. Rivers State, Nigeria. Sci. Africana, 8: 134-155

Tchokosse, P., Olomo, J.B. and Osibota, O.A., 1999. Radioactivity in the community water supplies of Ife-central and Ife-East L.G.A.'S Osun State, Nigeria. Nucl. Instr. and Methods, 422: 784-789
Torrealba, F., Sajo-Bohus, L., Greaves, E.D., Ferrer, H., Hazos, S. and Palfalvi, J., 1993. Radiation levels, greater interest in population centers in Venezuela. $43^{\text {rd }}$ Proc. Annual convention of the Association for science advancement, Merida, Venezuela 14-19 November. 1993. Acta. Cien. Ven. 44. Supl. 1:150.

US-EPA, 2001. Current drinking water Standard. United States Environmental Protection Agency, Washington DC, USA

WHO, 1993. Guidelines for Drinking Water Quality (Recommendations, Vol. 1). $2^{\text {nd }}$ Edn., World Health Organization, Geneva

WHO, 2003. Guidelines for drinking water quality. Third ed., World Health Organization, Geneva, Switzerland.

Yarar, Y. and E. Kam, 2005. Environmental radioactivity concentrations of Tekirdag. Int. Congr. Ser., 1276: 387-389 